\title{
Hepatic Mitochondria in Diet-induced Obese Mice (Stereology and Molecular Analysis)
}

\author{
Mitocondrias Hepáticas en Ratones Obesos Inducidos \\ por la Dieta (Estereología y Análisis Molecular)
}

\author{
Pedro Henrique Reis-Barbosa ${ }^{1,2}$; Jorge Jose de Carvalho ${ }^{2}$; Mariano del Sol ${ }^{3}$ \& Carlos Alberto Mandarim-de-Lacerda $^{1,3}$
}

REIS-BARBOSA, P. H.; CARVALHO, J. J.; DEL SOL, M. \& MANDARIM-DE-LACERDA, C. A. Hepatic mitochondria in dietinduced obese mice (stereology and molecular analysis). Int. J. Morphol., 39(2):571-576, 2021.

SUMMARY: The world population is going through an obesity epidemic that has severe consequences for the health system. This study focused on studying hepatic mitochondria in obese animals induced by a high-fat (HF) diet and used the model-based stereology in electron micrographs for the quantitative study. Besides, the gene expressions of molecular markers of mitochondrial biogenesis carnitine palmitoyltransferase 1a $(C p t 1 \alpha)$, mitochondrial transcription factor a (Tfam), uncoupling protein 3 (Ucp 3), and nuclear respiratory factor $1(\mathrm{Nrf} 1)$ were analyzed. The HF diet caused a weight gain of $+1820 \%$ comparing the control group (C) with the HF group (from $0.32 \pm 0.31 \mathrm{~g}$ to $5.5 \pm 0.39 \mathrm{~g}, P<0.001$ ). The HF group showed fat droplets in the hepatocyte cytoplasm (steatosis) and less dense and large mitochondria in transmission electron microscopy. The mitochondria size (cross-section) did not show a significant difference between the groups $\mathrm{C}$ and HF. However, the mitochondria numerical density per area was $30 \%$ less, the mitochondrial surface density (outer membrane) was $20 \%$ less, and the mitochondrial volume density was $22 \%$ less in the HF group than the C group. The gene expressions of molecular markers of mitochondrial biogenesis Cpt 1 $\alpha$, Tfam, Ucp 3, and Nrf 1 decreased in the HF group compared to the $\mathrm{C}$ group. The quantitative results match perfectly with the molecular ones of mitochondrial biogenesis markers. In the future, it will be crucial to verify if and how these data recover with the reduction of obesity, which would be of significant interest given the current obesity epidemic that affects the world population.

KEY WORDS: Mitochondria; Mitochondrial biogenesis; Diet-induced obesity; Cell biology; Molecular biology.

\section{INTRODUCTION}

Mitochondria are organelles involved in intracellular lipid trafficking, exchanging lipids with the rest of the cell at membrane contact sites (endoplasmic reticulummitochondria encounter structure or ERMES) (Kornmann, 2020). Mitochondria regulate ATP generation, cell proliferation, cell death, and metabolism, and the management of innate immunity and the inflammatory response (Missiroli et al., 2020). Dysfunctional mitochondria are implicated in several pathophysiological conditions such as cancer, neurodegeneration, and aging (Kumar et al., 2020) and target cell death regulation (Bock \& Tait, 2020).

Moreover, toxic agents might lead to mitochondrial membrane damage and internal membrane swelling, especially of hepatocytes (Dhanraj et al., 2020).
Mitochondria can be studied with quantitative morphological tools such as model-based stereology (Mandarim-deLacerda, 2011). Sometimes, although no qualitative differences might be observed, a quantitative study allows the determination of a higher mean volume, number, and surface density of mitochondria (Black \& Cornacchia, 1986). The significance of quantitative studies with mitochondria is because mitochondrial biogenesis includes mitochondrial proliferation and differentiation and is essential for tissue health through the balance of mitochondrial turnover (Whitaker et al., 2016).

The high-fat (HF) diet induces hepatic steatosis through multiple pathways: increasing hepatic inflow of fatty acids and hepatic fatty acid synthesis and decreasing fatty

\footnotetext{
${ }^{1}$ Laboratory of Morphometry, Metabolism, and Cardiovascular Diseases. Biomedical Centre, Institute of Biology, The University of the State of Rio de Janeiro (UERJ), Rio de Janeiro, Brazil.

${ }^{2}$ Laboratory of Ultrastructure and Tissue Biology. Biomedical Centre, Institute of Biology, The University of the State of Rio de Janeiro (UERJ), Rio de Janeiro, Brazil.

${ }^{3}$ Doctoral Program in Morphological Sciences, Universidad de La Frontera, Temuco, Chile.
} 
acid oxidation in the liver, overloading the mitochondrial capacity (Shin et al., 2019). Consequently, there is increased mitochondrial biogenesis and hepatocytes' interaction (Song et al., 2020).

This study aimed to observe the liver mitochondria's quantitative data and molecular markers of mitochondrial biogenesis related to diet-induced obesity in mice.

\section{MATERIAL AND METHOD}

\section{Experimental design: animals and diet}

All procedures are in accordance and approved by the Animal Ethics Committee of the University of State of Rio de Janeiro (Protocol number 047/2018).

Twenty 3-month-old C57BL/6 male mice were kept individually in a ventilated system under controlled conditions of light $\left(12 / 12 \mathrm{~h}\right.$ dark/light cycle), temperature $\left(21 \pm 2{ }^{\circ} \mathrm{C}\right)$, and humidity $(60 \pm 10 \%)$ (Nexgen, Allentown Inc., PA, USA), with free access to food and water during 15 weeks.

The animals were randomly assigned into two groups ( $n=10$ /group): control (C, fed a control diet with $19 \%$ of energy as protein; $17 \%$ as fat, and $64 \%$ as carbohydrates; total energy $15 \mathrm{~kJ} / \mathrm{g}$ ), and high-fat (HF, fed a high-fat diet with $19 \%$ of energy as protein; $49 \%$ as fat and $32 \%$ as carbohydrates; total energy $21 \mathrm{~kJ} / \mathrm{g}$ ). Diets were manufactured by PragSolucoes (Jau, SP, Brazil) following the recommendations for mature rodents (Aguila et al., 2021). The bodyweight of the animals was measured weekly.

\section{Sacrifice and tissue extraction}

The animals were food-deprived for six hours and killed under anesthesia (ketamine $60 \mathrm{mg} / \mathrm{kg}$ and xylazine $10 \mathrm{mg} / \mathrm{kg}$, intraperitoneal). The livers were dissected, and several $1 \mathrm{~mm}^{3}$ fragments from all lobes were fixed for $48 \mathrm{~h}$ in $2.5 \%$ glutaraldehyde (Riedel-de-Haen, Germany) in 0.1 $\mathrm{M}$ cacodylate buffer ( $\mathrm{pH} 7.2$ ) and post-fixed for $3 \mathrm{~h}$ in $1 \%$ osmium tetroxide (Sigma-Aldrich Louis, USA) or frozen at $-80{ }^{\circ} \mathrm{C}$ until analyses.

Fixed fragments were rinsed in PBS, dehydrated (graded series of acetone), and embedded in epoxy resin (Embed-812, EMS, Hatfield, PA, USA). Semithin sections $(1 \mu \mathrm{m})$ and ultrathin sections $(70 \mathrm{~nm})$ were obtained with a Leica Ultracut-UCT (Leica Mikrosysteme GmbH, Austria). Semithin sections were stained with toluidine blue and studied in a Nikon microscope model $80 \mathrm{i}$ and DS-Ri1 digital camera (Nikon Instruments, Inc., New York, USA). Ultrathin sections were counterstained with uranyl acetate and lead citrate and observed at $80 \mathrm{kV}$ transmission electron microscopy (JEOL, Akishima, Tokyo, Japan).

\section{Mitochondrial stereology}

The model-based stereology was assessed on electron micrographs superimposing a test-system composed of testlines $\left(\mathrm{L}_{\mathrm{T}}\right)$ and test-points $\left(\mathrm{P}_{\mathrm{T}}\right)$ in a frame with a known area $\left(\mathrm{A}_{\mathrm{T}}\right)$ (Mandarim-de-Lacerda \& del Sol, 2017). Briefly, in a random set of liver micrographs per group, mitochondrial data might be estimated by counting the mitochondrial profiles in $\mathrm{A}_{\mathrm{T}}\left(\mathrm{N}_{\mathrm{A}}\right)$, the mitochondrial surface intersections with the test line (I), and the points hitting the mitochondria $\left(\mathrm{P}_{\mathrm{p}}\right)$ as described previously (Reis-Barbosa et al., 2020). Therefore, we estimated the following data: a) $\mathrm{N}_{\mathrm{A}}$ [mito, liver] $:=\mathrm{N}$ [mito, liver] $/ \mathrm{A}_{\mathrm{T}} ; \underline{\mathrm{b}}$ ) volume density, $\mathrm{Vv}$ [mito, liver $]:=\mathrm{P}_{\mathrm{P}}[$ mito, liver $] / \mathrm{P}_{\mathrm{T}}$; ) surface density (outer membrane), $\mathrm{Sv}[$ mito, liver $]:=2 * I[$ mito, liver $] / \mathrm{L}_{\mathrm{T}} ; \mathrm{d}$ ) crosssectional mitochondrial area, $\mathrm{A}[\mathrm{mito}$, liver $]:=\mathrm{Vv}[\mathrm{mito} /$ liver $] / 2 \mathrm{~N}_{\mathrm{A}}$ [mito, liver $]$.

\section{Real-time polymerase chain reaction (RT qPCR)}

Total RNA of the liver $(30 \mathrm{mg}$ ) was extracted (Trizol, Invitrogen, CA, USA), and quantified (spectroscopy, Nanovue, GE Life Sciences), then one microgram was treated with DNAse I. Then, oligo (dT) primers for mRNA and Superscript III reverse-transcriptase were applied to the synthesis of the first-strand cDNA (thermocycler CFX96 (Bio-Rad, Hercules, CA, USA, and SYBR Green mix). The endogenous beta-actin was used to normalize the expression of the selected genes. After the pre-denaturation and polymerase-activation program $\left(4 \mathrm{~min}\right.$ at $\left.95^{\circ} \mathrm{C}\right), 44$ cycles of $95^{\circ} \mathrm{C}$ for $10 \mathrm{~s}$ and $60^{\circ} \mathrm{C}$ for $15 \mathrm{~s}$ the material followed a melting curve program $\left(60-95{ }^{\circ} \mathrm{C}\right.$, the heating rate of 0.1 ${ }^{\circ} \mathrm{C} / \mathrm{s}$ ). RT qPCR analyzed the expression intensities of the genes, and the ratio of relative mRNA expression was calculated using $2{ }^{-} \mathrm{CT}-{ }_{\mathrm{A}}^{\mathrm{CT}}$ as the difference between the number of cycles $(\mathrm{CT})$.

The primers were designed using Prime 3 software (http://bioinfo.ut.ee/primer3-0.4.0/). We studied the mitochondrial biogenesis markers: carnitine palmitoyltransferase 1a $\left(\begin{array}{lll}C p t & 1 a\end{array}\right)$ ( T G T C A A A G A T A C C G T G A G C A G, GCCCACCAGGATTTTAGCTT); mitochondrial transcription factor a (Tfam) (AAGGGAATGGGAAAGGTAGA, AACAGGACATGGAAAGCAGAT); mitochondrial uncoupling protein 3 (Ucp 3) (CAGATCCTGCTGCTACCTAAT, GCATCCATAGTCCCTCTGTAT); nuclear respiratory factor 1 ( Nrf 1$)$ (TGAGCTGCTGTCCAAATACC, ACCTTCTGCTTCATCTGTCG). 


\section{Data analysis}

The data are shown as the means and standard deviations, analyzed by the unpaired t-test and Welch correction (Prism version 9.01 for Windows, GraphPad Software, La Jolla, CA, USA).

\section{RESULTS}

\section{Weight gain}

The HF diet caused a weight gain of $+1820 \%$ comparing the $\mathrm{C}$ group with the HF group (from $0.32 \pm 0.31$ $\mathrm{g}$ to $5.5 \pm 0.39 \mathrm{~g}, \mathrm{P}<0.001)$.
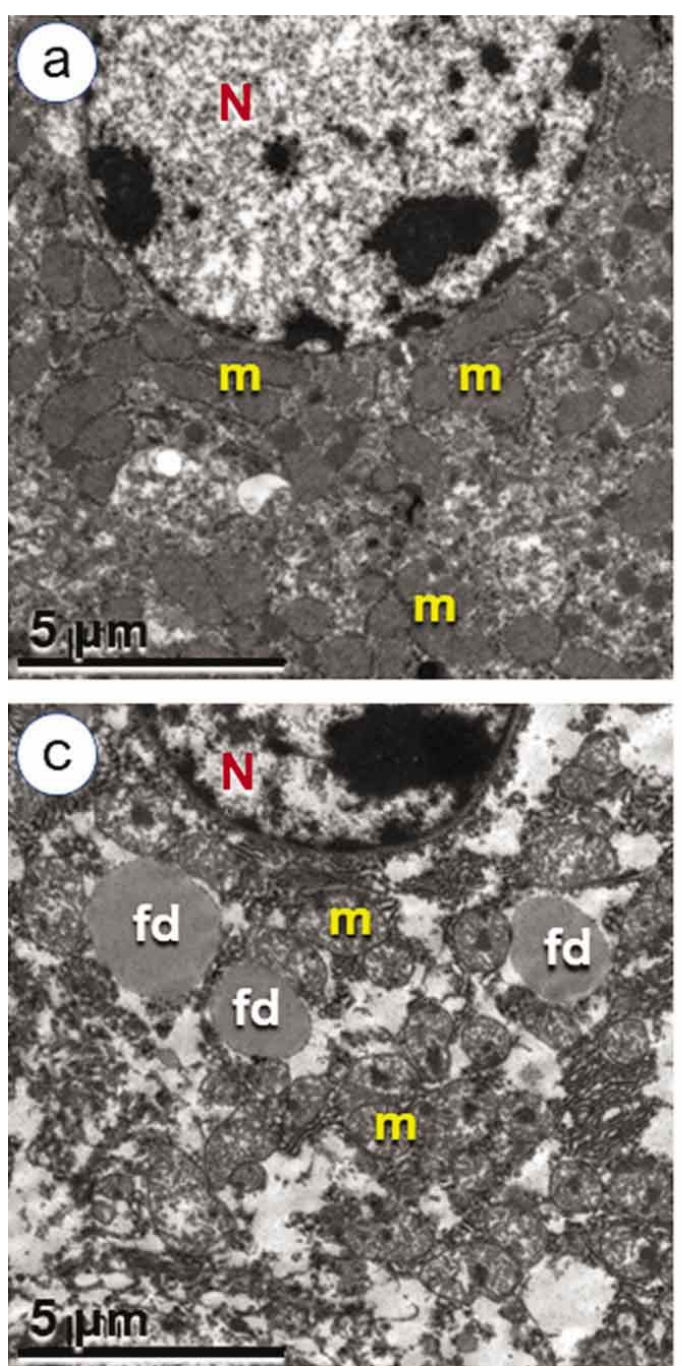

Fig. 1. Electron micrographs of hepatocytes (different magnifications) in the control (C) group (a and b) and the high-fat (HF) group (c and d). Mitochondria $(\mathrm{m})$ are more electron-dense and appear grouped closer to the nucleus $(\mathrm{N})$ in the $\mathrm{C}$ group than the HF group, probably because the cytoplasm contains numerous fat droplets (fd) in the HF group, which interpose between the mitochondria.

\section{Liver mitochondria}

\section{a. Stereology}

The effect of chronic HF dietary intake appears in the hepatocytes' ultrastructural study. Compared with the control group fed a balanced diet, the HF group showed fat droplets in the hepatocyte cytoplasm (steatosis) and less dense and seemingly large mitochondria (Fig. 1).

The mitochondria size (cross-section) did not show a significant difference between the groups $\mathrm{C}$ and $\mathrm{HF}$. However, the mitochondria numerical density per area was $30 \%$ less, the mitochondrial surface density (outer membrane) was 20 $\%$ less, and the mitochondrial volume density was $22 \%$ less in the HF group than the $\mathrm{C}$ group (Table 1).
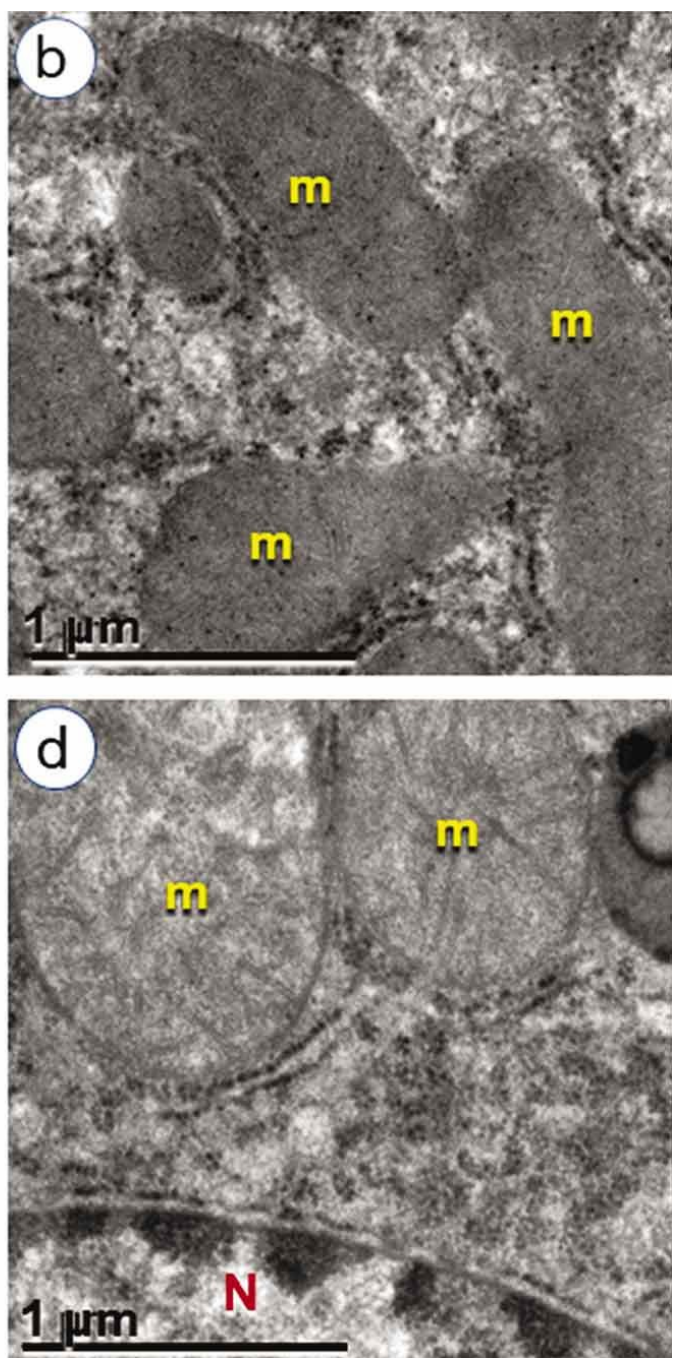
Table I. We compared the liver mitochondria in the groups C and HF with model-based stereology. Data are mean \pm standard deviation (unpaired t-test and Welch correction, Prism v. 9.01 for Windows, GraphPad Software, La Jolla, CA, USA) in a sample of five animals per group.

\begin{tabular}{llll}
\hline Data & C & HF & $P$ \\
\hline A [mito, liver $]\left(\mu \mathrm{m}^{2}\right)$ & $0.30 \pm 0.04$ & $0.34 \pm 0.05$ & $\mathrm{~ns}$ \\
$\mathrm{~N}_{\mathrm{A}}[\mathrm{mito}$, liver $]\left(10^{\left.3 / \mathrm{mm}^{2}\right)}\right.$ & $459 \pm 0.2$ & $315 \pm 0.3$ & $<0.001$ \\
$\mathrm{~S}_{\mathrm{V}}\left[\right.$ mito, liver] $\left(\mathrm{mm}^{\left.2 / \mathrm{mm}^{3}\right)}\right.$ & $1223 \pm 122.3$ & $976 \pm 120.6$ & 0.02 \\
$\mathrm{~V}_{\mathrm{V}}[$ mito, liver $(\%)$ & $27 \pm 1.2$ & $21 \pm 3.1$ & 0.01 \\
\hline
\end{tabular}

Abbreviations: A, cross-sectional area; $\mathrm{C}$, control group; $\mathrm{HF}$, high-fat group; mito, mitochondria; $\mathrm{ns}$, not significant; $\mathrm{P}$, probability; $\mathrm{N}_{\mathrm{A}}$, numerical density per area; $\mathrm{S}_{\mathrm{v}}$, surface density; $\mathrm{V}_{\mathrm{v}}$ volume density.

\section{b. Molecular biogenesis markers}

The molecular markers of mitochondrial biogenesis decreased in the HF group compared to the C group (Fig. 2).
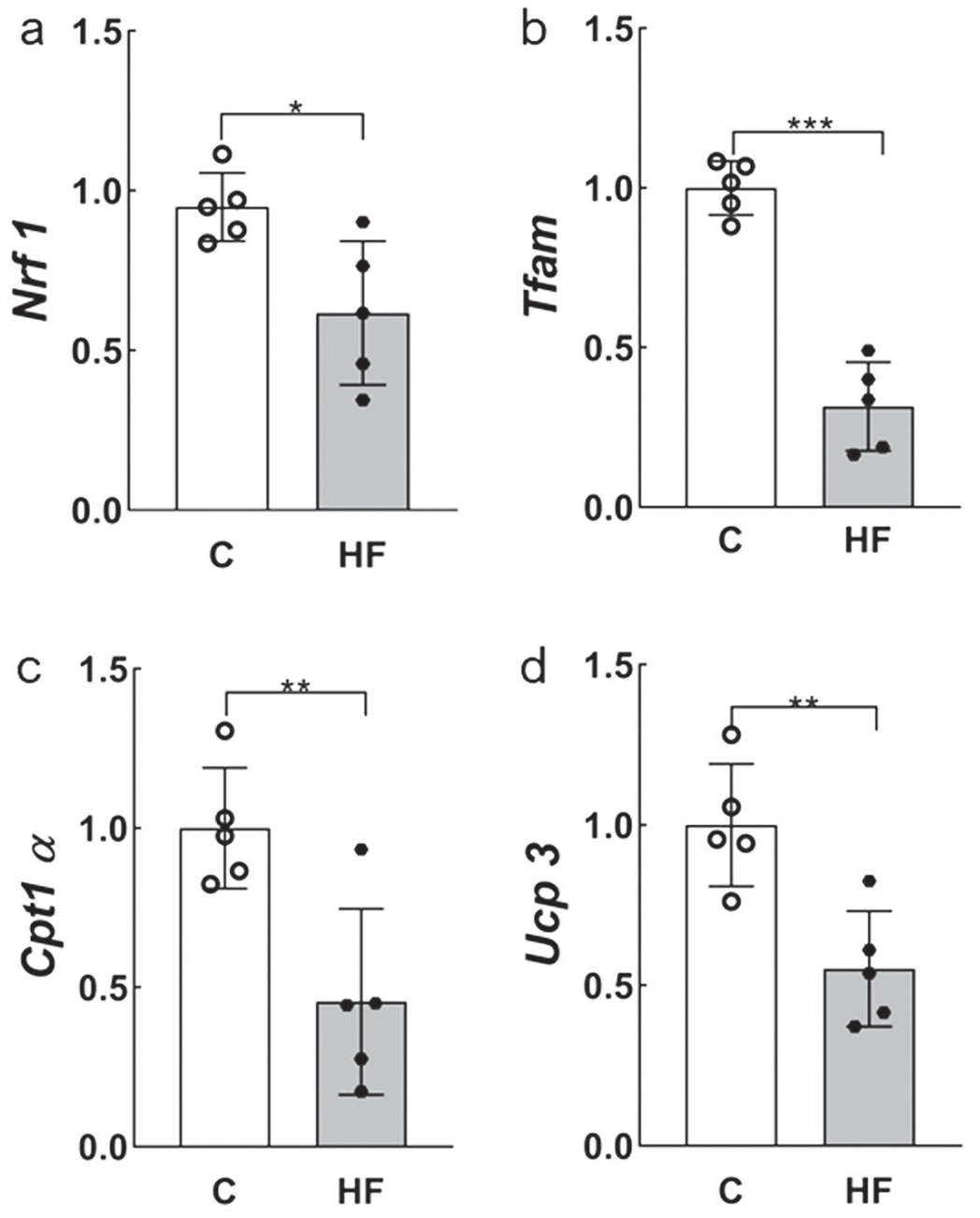

\section{DISCUSSION}

An intervention in the consumed diet can affect various metabolic pathways in different organs and tissues (Bargut et al., 2017; Cioffi et al., 2017). In the current study with diet-induced obesity, there were changes in mitochondrial biogenesis in hepatocytes. We demonstrated overwhelming changes in the hepatocyte due to diet-induced obesity in mice. These changes were observed at the ultrastructural and molecular levels. The quantitative mitochondrial data and the molecular markers of mitochondrial biogenesis were significantly reduced because of diet-induced obesity.

The HF diet was responsible, as expected, for an impressive weight gain in the animals saturating the white adipose tissue's packaging capacity. Then, the excess of fat is accumulated in non-adipose tissues, like the liver (Barbosa-da-Silva et al., 2013), with consequent effect on the mitochondrial oxygen consumption, mitochondrial volume, and inner membrane surface (Schwerzmann et al., 1986). All conditions triggered by the HF diet can significantly worsen hepatocytes, thus establishing a close relationship between mitochondrial biogenesis and respiration, and caused hepatocyte nuclear and mitochondrial cristae modifications with low capacity beta-oxidation (LopezLluch, 2017). 
The mitochondrial biogenesis related genes, including Nrfl, Tfam, Cpt-1 $\alpha$, and Ucp3, were downregulated because of the diet-induced obesity. The transcriptions of $\mathrm{Nrfl}$ and Tfam are master regulators of mitochondrial biogenesis linked to obesity in mice (Veiga et al., 2017; Kozhukhar \& Alexeyev, 2019). Thus, dietinduced obesity results in a distribution of Tfam gene expression in a minor abundant mitochondrial population, indicating that the HF diet decreased mitochondrial differentiation (Song et al., 2020).

The alteration of mitochondria by lipid intake is mediated by the activation of mitochondrial biogenesis generated by Tfam, Pgc-1, and Nrf-1 (Davari et al., 2020). In general, Tfam is regulated by the Pgc-1 coactivator, and $\mathrm{Nrf-1}$ binds together and forms a heterodimer for regulating mitochondrial function (Lu et al., 2020). The binding of Nrf-1 and Pgc-1 coactivator improves the transcription of Nrf-1 (Davari et al., 2020). Here, it is noteworthy to note that these pathways were lessened, corroborating mitochondrial bioenergetics' impairment linked with diabetes and fatty liver (Aguila et al., 2010).

In conclusion, the present study provides essential preliminary information about how the liver mitochondria of obese animals are depressed, which is relevant because of this organelle's bioenergetic role. The quantitative findings match perfectly with the molecular ones of mitochondrial biogenesis markers. Therefore, it will be crucial for future verification if and how these data recover with the reduction of obesity, which would be of significant interest given the current obesity epidemic that affects the world population.

\section{ACKNOWLEDGMENTS}

The authors would like to thank Aline Penna and Ana Lucia Rosa Nascimento for their technical assistance. We are grateful for the Fundação Oswaldo Cruz facility to study transmission electron microscopy (Plataforma de Microscopia Eletrônica Rudolph Barth).

\section{FINANCIAL SUPPORT}

The study was supported by Conselho Nacional de Desenvolvimento Científico e Tecnológico, CNPq (Brazil), Fundação Carlos Chagas Filho de Amparo à Pesquisa do Estado do Rio de Janeiro (Faperj, Brazil). PHRB received a bursary from Coordenação de Aperfeiçoamento de Pessoal de Nível Superior - Brazil (CAPES) - Finance Code 001. These foundations had no interference in the accomplishment and submission of the study.
REIS-BARBOSA, P. H.; CARVALHO, J. J.; DEL SOL, M. \& MANDARIM-DE-LACERDA, C. A. Mitocondrias hepáticas en ratones obesos inducidos por la dieta (estereología y análisis molecular). Int. J. Morphol., 39(2):571-576, 2021.

RESUMEN: La población mundial atraviesa una epidemia de obesidad que tiene graves consecuencias para el sistema de salud. Este estudio se centró en el análisis de las mitocondrias hepáticas en animales obesos inducidos por una dieta alta en grasas (HF) y utilizó la estereología basada en modelos en micrografías electrónicas para el estudio cuantitativo. Además, se analizaron las expresiones génicas de los marcadores moleculares de la biogénesis mitocondrial carnitina palmitoiltransferasa 1a (Cpt 1 $\alpha)$, factor de transcripción mitocondrial a (Tfam), proteína desacoplante $3\left(U_{c p} 3\right)$ y factor respiratorio nuclear 1 ( Nrf 1). La dieta HF provocó un aumento de peso de $+1820 \%$ comparando el grupo de control (C) con el grupo HF (de 0,32 $\pm 0,31$ g a 5,5 $\pm 0,39 \mathrm{~g}, P$ $<0,001)$. El grupo HF mostró gotas de grasa en el citoplasma de los hepatocitos (esteatosis) y mitocondrias menos densas y grandes en la microscopía electrónica de transmisión. El tamaño de las mitocondrias (sección transversal) no mostró una diferencia significativa entre los grupos C y HF. Sin embargo, la densidad numérica de mitocondrias por área fue $30 \%$ menor, la densidad de superficie mitocondrial (membrana externa) fue $20 \%$ menor y la densidad de volumen mitocondrial fue $22 \%$ menor en el grupo HF que en el grupo C. Las expresiones génicas de los marcadores moleculares de la biogénesis mitocondrial Cpt $1 \alpha$, Tfam, Ucp 3 y Nrf 1 disminuyeron en el grupo HF en comparación con el grupo C. Los resultados cuantitativos coinciden perfectamente con los moleculares de los marcadores de biogénesis mitocondrial. En el futuro, será crucial verificar si estos datos se recuperan y cómo se recuperan con la reducción de la obesidad, lo que sería de gran interés dada la actual epidemia de obesidad que afecta a la población mundial.

PALABRAS CLAVE: Mitocondrias; Biogénesis Mitocondrial; Obesidad inducida por la dieta; Biología celular; Biología molecular.

\section{REFERENCES}

Aguila, M. B.; Ornellas, F. \& Mandarim-de-Lacerda, C. A. Nutritional research and fetal programming: parental nutrition influences the structure and function of the organs. Int. J. Morphol., 39:327-34, 2021 (doi: 10.4067/S0717-95022021000100327).

Aguila, M. B.; Santos, C. F.; Pinheiro-Mulder, A. R.; Faria, T.S. \& Mandarim-de-Lacerda, C.A. 2010. Hepatic insulin resistance and nonalcoholic fatty liver disease. In: Molière, J. \& Gauthier, L., editors. Insulin resistance: symptoms, causes, and treatment. Hauppauge, NY: Nova Science Pu. p 1-44.

Barbosa-da-Silva, S.; da Silva, N.C.; Aguila, M. B. \& Mandarim-deLacerda, C. A. Liver damage is not reversed during the lean period in diet-induced weight cycling in mice. Hepatol. Res., 44:450-9, 2013 (doi: 10.1111/hepr.12138)

Bargut, T.C.L.; Souza-Mello, V.; Aguila, M.B. \& Mandarim-de-Lacerda, C.A. Browning of white adipose tissue: lessons from experimental models. Horm. Mol. Biol. Clin. Investig., 31, 2017 (doi: 10.1515/hmbci2016-0051) 
Black, V. H. \& Cornacchia, L., 3rd. Stereological analysis of peroxisomes and mitochondria in intestinal epithelium of patients with peroxisomal deficiency disorders: Zellweger's syndrome and neonatal-onset adrenoleukodystrophy. Am. J. Anat., 177:107-18, 1986.

Bock, F.J. \& Tait, S.W.G. Mitochondria as multifaceted regulators of cell death. Nat. Rev. Mol. Cell. Biol., 21:85-100, 2020 (doi: 10.1038/s41580019-0173-8).

Cioffi, F.; Senese, R.; Lasala, P.; Ziello, A.; Mazzoli, A.; Crescenzo, R.; Liverini, G.; Lanni, A.; Goglia, F. \& Iossa, S. Fructose-Rich Diet Affects Mitochondrial DNA Damage and Repair in Rats. Nutrients, 9, 2017 (doi: 10.3390/nu9040323).

Davari, F.; Alimanesh, Z.; Alimanesh, Z.; Salehi, O. \& Hosseini, S. A. Effect of training and crocin supplementation on mitochondrial biogenesis and redox-sensitive transcription factors in livertissue of type 2 diabetic rats. Arch. Physiol. Biochem., 1-6, 2020 (doi: 10.1080/ 13813455.2020.1762663).

Dhanraj, P.; Venter, C.; Bester, M. J. \& Oberholzer, H. M. Induction of hepatic portal fibrosis, mitochondria damage, and extracellular vesicle formation in Sprague-Dawley rats exposed to copper, manganese, and mercury, alone and in combination. Ultrastruct. Pathol.: -11, 2020 (doi: 10.1080/01913123.2020.1731638).

Kornmann, B. The endoplasmic reticulum-mitochondria encounter structure: coordinating lipid metabolism across membranes. Biol. Chem., 2020 (doi: 10.1515/hsz-2020-0102).

Kozhukhar, N. \& Alexeyev, M. F. Limited predictive value of TFAM in mitochondrial biogenesis. Mitochondrion, 49:156-65, 2019 (doi: 10.1016/j.mito.2019.08.001)

Kumar, N.; Qian, W. \& Van Houten, B. Sick mitochondria cause telomere damage: implications for disease. Mol. Cell Oncol., 7:1678362, 2020 (doi: 10.1080/23723556.2019.1678362).

Lopez-Lluch, G. Mitochondrial activity and dynamics changes regarding metabolism in ageing and obesity. Mech. Ageing Dev., 162:108-21, 2017 (doi: 10.1016/j.mad.2016.12.005).

Lu, K.; Policar, T.; Song, X. \& Rahimnejad, S. Molecular Characterization of PGC-1beta (PPAR Gamma Coactivator 1beta) and its Roles in Mitochondrial Biogenesis in Blunt Snout Bream (Megalobrama amblycephala). Int. J. Mol. Sci., 21, 2020 (doi: 10.3390/ijms21061935).

Mandarim-de-Lacerda, C.A. 2011. Morphometry and stereology in electron transmission microscopy. In: De-Souza, W., editor. Electron microscopy techniques applied to the life sciences, 3rd ed. Rio de Janeiro, RJ: Sociedade Brasileira de Microscopia e Microanálise. p 423.

Mandarim-de-Lacerda, C.A. \& del Sol, M. Tips for studies with quantitative morphology (morphometry and stereology). Int. J. Morphol., 35:148294, 2017 (doi: 10.4067/S0717-95022017000401482).

Missiroli, S.; Genovese, I.; Perrone, M.; Vezzani, B.; Vitto, V.A.M. \& Giorgi, C. The Role of Mitochondria in Inflammation: From Cancer to Neurodegenerative Disorders. J. Clin. Med., 9, 2020 (doi: 10.3390/ jem9030740).

Reis-Barbosa, P. H.; Carvalho, J. J.; del Sol, M. \& Mandarim-de-Lacerda, C.A. Commentary on mitochondrial stereology in transmission electron microscopy. Int. J. Morphol., 38:26-9, 2020 (doi: 10.4067/S071795022020000100026).

Schwerzmann, K.; Cruz-Orive, L. M.; Eggman, R.; Sanger, A. \& Weibel, E.R. Molecular architecture of the inner membrane of mitochondria from rat liver: a combined biochemical and stereological study. J. Cell Biol., 102:97-103, 1986.

Shin, S. K.; Cho, H. W.; Song, S. E.; Bae, J. H.; Im, S. S.; Hwang, I.; Ha, H. \& Song, D. K. Ablation of catalase promotes non-alcoholic fatty liver via oxidative stress and mitochondrial dysfunction in diet-induced obese mice. Pflugers Arch, 471:829-43, 2019 (doi: 10.1007/s00424-01802250-3).

Song, YF; Hogstrand, C.; Ling, S.C.; Chen, G.H. \& Luo, Z. Creb-Pgc1alpha pathway modulates the interaction between lipid droplets and mitochondria and influences high fat diet-induced changes of lipid metabolism in the liver and isolated hepatocytes of yellow catfish. $J$. Nutr. Biochem., 80:108364, 2020 (doi: 10.1016/j.jnutbio.2020.108364).
Veiga, F. M. S.; Graus-Nunes, F.; Rachid, T. L. ; Barreto, A. B.; Mandarimde-Lacerda, C. A. \& Souza-Mello, V. Anti-obesogenic effects of WY14643 (PPAR-alpha agonist): Hepatic mitochondrial enhancement and suppressed lipogenic pathway in diet-induced obese mice. Biochimie, 140:106-16, 2017 (doi: 10.1016/j.biochi.2017.07.003).

Whitaker, R.M.; Corum, D.; Beeson, C.C. \& Schnellmann, R.G. Mitochondrial Biogenesis as a Pharmacological Target: A New Approach to Acute and Chronic Diseases. Annu. Rev. Pharmacol. Toxicol., 56:229-49, 2016 (doi: 10.1146/annurev-pharmtox-010715103155).

Corresponding author:

Carlos Alberto Mandarim-de-Lacerda

Laboratório de Morfometria, Metabolismo

e Doença Cardiovascular

Centro Biomédico

Instituto de Biologia

Universidade do Estado do Rio de Janeiro

Rio de Janeiro

BRASIL

E-mail:mandarim@uerj.br

Web page: http://www.Immc.uerj.br/

https://orcid.org/: 0000-0003-4134-7978

Received: 13-02-2021

Accepted: 27-02-2021 